\title{
STRATEGI KAMPANYE PARTAI NASIONALIS: PENGALAMAN PARTAI NASDEM PADA PEMILU 2019
}

\author{
Andi Muhammad Sary Sakti ${ }^{1}$, Ridho Al-Hamdi ${ }^{2}$, Bachtiar Dwi Kurniawan ${ }^{3}$ \\ 1,2,3 Program Studi Ilmu Pemerintahan Universitas Muhammadiyah Yogyakarta \\ Email: andisarisakti@gmail.com ${ }^{1}$, ridhoalhamdi@umy.ac.id ${ }^{2}$, bachtiar.dk@gmail.com ${ }^{3}$
}

\begin{abstract}
Abstrak
Artikel ini mengkaji tentang strategi kampanye Partai Nasdem pada Pemilihan Legislatif 2019. Dipilihnya Nasdem sebagai obyek kasus dalam penelitian ini karena Nasdem sebagai partai baru berhasil dalam kampanye politik pada Pemilu 2019 dan merupakan partai yang mengalami peningkatan tertinggi dari pemilu sebelumnya dibanding partai-partai yang lainnya. Padahal biasanya partai baru tidak selalu berhasil dalam meraih kursi ke parlemen seperti halnya pada Pemilu 2019 yang tidak ada satu pun partai politik baru yang lolos ambang batas parlemen. Selain itu, ketika sejumlah survei mengatakan bahwa Nasdem tidak bakal lolos ambang batas parlemen, kenyataannya partai nasionalis ini meraih posisi lima partai besar pada Pemilu 2019. Karena itu, artikel ini menarik untuk menginvestigasi strategi kampanye Nasdem pada Pemilu 2019. Secara teoritis, strategi kampanye Nasdem akan dianalisa dengan kerangka empat indikator teori pemasaran bauran (mix marketing) yang dikenal dengan 4P, yaitu product, price, place, promotion. Secara metodologis, artikel ini merupakan hasil penelitian kualitatif dengan pendekatan studi kasus. Teknik pengumpulan data yang digunakan adalah studi dokumentasi terutama terhadap media massa online. Temuan dari penelitian ini adalah bahwa dari empat indikator pemasaran bauran yang digunakan oleh Nasdem, indikator price (harga) adalah indikator yang paling mempengaruhi kemenangan Nasdem pada Pemilu 2019, terutama pada harga citra yang disimbolkan pada kekuatan sosok Surya Paloh. Selain itu, citra Nasdem sebagai partai pendukung capres petahana Jokowi juga turut mempengaruhi besarnya perolehan suara Nasdem pada Pemilihan Legislatif 2019.
\end{abstract}

\author{
Kata Kunci: \\ Nasdem, Surya Paloh, Strategi Kampanye, Pemilu 2019, Politik Tanpa Mahar
}

\begin{abstract}
This article examines the campaign strategy of the National Democrat Party (Nasdem) in Indonesia's 2019 legislative election. Nasdem was selected as the research object because Nasdem as a new party succeeded in political campaigns in the 2019 election and was the party that experienced the highest increase in vote from previous elections compared to the other parties. Commonly, new parties cannot succeed in reaching the parliamentary threshold. However, it is not applied for Nasdem. While most surveys predicted that Nasdem would not succeed in passing the 4 percent of the parliamentary threshold, the party proved that they were being the big five-party in the 2019 election. Theoretically, the Nasdem campaign strategy is analyzed with four mix marketing
\end{abstract}


indicators so-called as 4P, namely product, price, place, and promotion, This research is a qualitative research, using the case study approach. In data-gathering, it employs a documentary study by collecting news of online mass media. The research finding demonstrates that among four mix marketing indicators to assess the Nasdem campaign strategy, price is the most influential indicator which affects the triumph of Nasdem in the 2019 legislative election, primarily the image price symbolized by the robust personality of Surya Paloh. In addition to that, the Nasdem image as the Jokowi true believer also strengthens the high popular vote of Nasdem in the 2019 legislative election.

\section{Keywords:}

Nasdem, Surya Paloh, Campaign Strategy, 2019 Election, Politics without Dower

\section{Pendahuluan}

Pemilu 2019 merupakan pemilu dengan iklim politik yang penuh persaingan, meskipun kampanye terbuka dimulai pada Pemilu 2009, akan tetapi puncak dari keterbukaan pemilu terjadi pada tahun 2014 dan 2019. Kemajuan teknologi yang mengharuskan partai politik "bergerilya" di sosial media, yang sebelumnya partai hanya mengandalkan media massa seperti televisi, koran, dan radio, kini mereka harus lebih variatif untuk melakukan kampanye demi menarik perhatian kaum milenial.

Strategi politik yang dilakukan oleh partai politik terhadap masyarakat sangat diperlukan dalam menghadapi sebuah pemilu. Keberhasilan suatu strategi politik oleh partai politik dalam merencanakan dan melaksanakan, akan ikut berperan pada hasil perolehan suara partai politik dalam pemilu. Partai politik yang berpartisipasi dalam pemilu akhir-akhir ini juga harus bekerja ekstra, karena melihat tingkat kepercayaan masyarakat terhadap partai politik menurun dari tahun ke tahun. pada pemilu pasca Reformasi tahun 1999 jumlah Golput (Golongan Putih) mencapai angka 7,3\%, pada Pemilu 2004 meningkat 15,9\%, Pemilu 2009 juga meningkat hingga mencapai angkat 29,1\%, Pemilu 2014 dan 2019 jumlah golput berada di sekitar 25-30\%. Fakta tersebut menunjukkan bahwa masyarakat kehilangan kepercayaan terhadap partai politik. ${ }^{1}$

Secara konseptual, banyak kajian yang telah mendefinisikan tentang partai politik. Partai politik dapat dipahami sebagai sekelompok orang yang terikat kuat oleh keyakinan yang sama, kepentingan yang sama, dan komitmen yang sama untuk

${ }^{1}$ Fadli Ramadhanil, Veri Junaidi \& Ibrohim, Desain Partisipasi Masyarakat Dalam Pemantauan Pemilu, Desain Partisipasi Masyarakat Dalam Pemantauan Pemilu (Jakarta: Kemitraan bagi Pembaruan Tata Pemerintahan di Indonesia bekerjasama Perludem, 2015). 
mewujudkan kepentingan-kepentingan mereka, menawarkan sebuah kebijakan alternatif untuk pemerintahan atau menduduki jabatan publik tertentu dengan catatan cara meraih kekuasaan tersebut melalui jalur sah, legal, dan konstitusional. ${ }^{2}$

Di tengah ketidakpercayaan masyarakat terhadap partai politik, muncul Partai Nasional Demokrat (selanjutnya ditulis Nasdem) yang baru deklarasi pada tahun 25-26 Januari 2013 siap mewujudkan perubahan melalui visinya yaitu Restorasi Indonesia, dan mengikuti pemilu pertamanya pada tahun 2014, Nasdem langsung mendapatkan Nomor Urut 1 pada keikutsertaannya di Pemilu 2014, dan langsung menunjukkan hasil yang positif serta prestasi yang lebih membanggakan pada Pemilu 2019.

Jika melihat persentase perolehan suara pada Pemilu 2014 dan 2019, Nasdem selaku partai yang baru dua kali mengikuti pemilu yaitu tahun 2014 dan 2019 memiliki perbandingan perolehan suara yang sangat jauh berbeda. Pada Pemilu 2014, diikuti 10 partai politik. Nasdem berhasil mendapatkan 6,72\% dan berhasil mendapatkan 35 kursi di DPR, mengungguli partai PPP dan Hanura yang notabene lebih dulu berpartisipasi dalam Pemilu 2009. Berikut adalah hasil perolehan suara Pemilu 2014: PDI-P 18,95\%, Golkar 14,75\%, Gerindra 11,81\%, Demokrat 10,19\%, PKB 9,04\%, PAN 7,59\%, PKS $6,79 \%$, Nasdem 6,72\%, PPP 6,53\%, Hanura 5,26\%, PBB 1,46\%, PKPI 0,91\%. ${ }^{3}$

Sedangkan pada Pemilu 2019, yang diikuti sebanyak 16 partai politik yang ikut berpartisipasi satu di antaranya adalah Nasdem. Pemilu 2019 merupakan pemilu kedua yang dikuti oleh Nasdem, dan berhasil masuk lima besar dengan persentase suara 9,05\%, Nasdem berhasil naik dua peringkat, yang awalnya berada di peringkat tujuh pada Pemilu 2014, naik ke peringkat lima pada Pemilu 2019. Berikut perolehan suara Pemilu 2019: PDI-P 19,33\%, Gerindra 12,57\%, Golkar 12,31\%, PKB 9,69\%, Nasdem 9,05\%, PKS 8,21\%, Demokrat 7,77\%, PAN 6,84\%, PPP 4,52\%, Perindo 2,67\%, Berkarya 2,09\%, PSI 1,89\%, Hanura 1,54\%, PBB 0,79\%, Garuda 0,50\%, dan PKPI $0,22 \%{ }^{4}$

${ }^{2}$ S. Neumann, "Toward a Comparative Study of Political Parties" dalam H. Eckstein \& D.E. Apter (Eds.) Comparative Politics: A Reader (New York: The Free Press, 1963), h. 351-367.

${ }^{3}$ Dani Prabowo, "Disahkan KPU, Ini Perolehan Suara Pemilu Legislatif 2014" dalam https:// nasional.kompas.com/read/2014/05/09/2357075/Disahkan.KPU.Ini.Perolehan.Suara.Pemilu.Legislatif.20 14 diakses 3 Maret 2020.

4 Komisi Pemilihan Umum RI, "Hasil Hitung Suara Legislatif DPR RI 2019" dalam https://pemilu2019.kpu.go.id/\#/dprri/hitung-suara/ diakse 1 Maret 2020. 
Melihat data di atas, Nasdem mengalami peningkatan signifikan yang pada Pemilu 2014 hanya menduduki peringkat delapan dengan perolehan suara 6,68\% dan pada Pemilu 2019 berhasil menduduki peringkat lima dengan perolehan suara 9,05\%, mengalami peningkatan suara sebesar 2,37\%. Keberhasilan Nasdem meningkatkan perolehan suara benar-benar di luar dugaan. Di saat partai-partai besar lainnya seperti Golkar, Demokrat dan PAN mengalami penurunan perolehan suara, Nasdem malah mencatatkan perolehan suara yang membanggakan di Pemilu 2019.

Hasil pemilu di atas sangat berbeda dengan hasil survei yang dilakukan berbagai lembaga-lembaga survei yang ada di Indonesia. Misalnya, Lingkar Survei Indonesia (LSI) Denny JA menunjukkan bahwa Nasdem termasuk lima partai yang terancam tidak lolos ambang batas parlemen yang telah ditetapkan yaitu 4\%. Survei yang dilaksanakan pada tanggal 18 hingga 26 Maret 2019 menggunakan metode multistage random sampling dengan responden berjumlah 1.200 orang, hasil survei bahwa lima partai yang peluang lolos dan tidak sama besarnya, yaitu Nasdem, PKS, PAN, PPP, dan Perindo. ${ }^{5}$

Data survei dari LIPI juga mengatakan Nasdem tidak akan lolos dalam ambang batas parlemen yang telah ditentukan sebelumnya yaitu 4\%. Menurut survei LIPI, perolehan suara Nasdem berada di bawah 4\%. Dalam survei LIPI yang dilaksanakan pada tanggal 19 April sampai dengan tanggal 5 Mei 2018, survei tersebut melibatkan 2.100 responden, Margin of Error (MoE) sebesar 2,4\% dengan tingkat kepercayaan 95\%. Hasil survei LIPI, elektabilitas Nasdem berada di angka 2,1\%. ${ }^{6}$

Survei dari Litbang Kompas juga menunjukkan bahwa Nasdem tidak akan melewati ambang batas parlemen pada Pemilu 2019. Menurut survei Litbang Kompas yang dilaksanakan pada tanggal 22 Februari sampai 5 Maret, Nasdem hanya memperoleh suara 2,6\%. Hanya ada enam partai politik yang di atas elektabilitas menurut data survei Litbang Kompas, yaitu PDI-P 26,9\%, Gerindra 17,0\%, Golkar

5 jpnn.com, "Peringkat Partai Politik Hasil Survei LSI Denny JA: Perindo di Atas PAN, PPP, Nasdem" dalam https://www.jpnn.com/news/peringkat-parpol-hasil-survei-lsi-denny-ja-perindo-di-ataspan-ppp-nasdem diakses 1 Maret 2020.

6 Andhika Prasetya, "Dapat 2,1\% di Survei, NasDem: Keliru Jika Tak Lolos DPR" dalam https://news.detik.com/berita/d-4124197/dapat-21-di-survei-nasdem-keliru-jika-tak-lolos-dpr diakses 1 Maret 2020. 
9,4\%, PKB 6,8\%, Demokrat 4,6\%, serta PKS 4,5\%. Sementara Nasdem tidak masuk dalam partai yang lolos elektabilitas pada survei Litbang Kompas. ${ }^{7}$

Sedangkan, lembaga survei Indobarometer yang melakukan survei pada tanggal 1 sampai 7 April 2019, responden berjumlah 1.200 orang dengan tingkat kepercayaan 95\% mengklasifikasikan partai peserta Pemilu 2019 dengan tiga kelas yaitu papan atas atau partai pemenang diisi partai besar yaitu PDI-P dan Gerindra. Papan tengah atau partai kemungkinan antara lolos dan tidak lolos sama besar peluangnya, diisi oleh Nasdem, Golkar, PKS, PKB, Demokrat, PPP, PAN, dan Perindo. Papan bawah atau partai yang diyakini tidak lolos ambang batas diisi oleh partai Berkarya, PSI, Hanura, PBB, PKPI, dan Partai Garuda. ${ }^{8}$

Berdasarkan dari data-data yang dihimpun tersebut, Nasdem sebagai partai baru bisa 'berbicara banyak' di Pemilu 2019. Perolehan suara yang dimiliki Nasdem juga mematahkan prediksi lembaga-lembaga survei yang menunjukkan Nasdem tidak akan lolos pada Pemilu 2019. Karena itu, penting untuk dianalisa lebih mendalam tentang strategi kampanye yang dilakukan oleh Nasdem pada Pemilu 2019. Tujuan dari penelitian ini adalah untuk mengetahui strategi kesuksesan kampanye Nasdem sebagai partai baru dan mewakili partai kategori nasionalis-sekuler.

\section{Studi Terdahulu}

Artikel ini mencoba untuk mereview sejumlah penelitian terdahulu dari berbagai jurnal ilmiah yang berbeda-beda namun berkaitan dengan strategi partai politik pada saat kampanye di momen pemilu. Tujuan dari penulisan penulisan kajian-kajian terdahulu adalah untuk meletakkan posisi kebaharuan dari kajian yang dilakukan oleh artikel ini.

Lindawati (2013) menganalisa tentang strategi partai politik dalam menghadapi Pemilu 2014 di tengah kondisi di mana kepercayan masyarakat Indonesia menurun terhadap partai politik. Temuan Lindawati menunjukkan, bahwa partai politik harus mengorganisir kegiatan kampanye untuk memenangkan pemilu. Kampanye politik

\footnotetext{
7 Ihsanuddin, "Survei Litbang "Kompas", 7 Partai politik Terancam Tak Lolos Ke Senayan" dalam https://nasional.kompas.com/read/2019/03/21/08302401/survei-litbang-kompas-7-partai politikterancam-tak-lolos-ke-Senayan?page=all diakses 4 Maret 2020.

8 Nanda Perdana Putra, "Hasil Survei Pileg 2019, Siapa Lolos Masuk Parlemen?" dalam https://www.liputan6.com/news/read/3934050/hasil-survei-pileg-2019-siapa-lolos-masuk-parlemen diakses 1 Maret 2020.
} 
harus dilakukan terus-menerus, tidak hanya dalam masa pemilu agar masyarakat akrab dengan partai politik dan mudah mendapatkan suara dan citra politik dari masyarakat. Selain itu, partai politik juga harus melakukan strategi push marketing (mobilisasi dan berburu pendukung) dan pull marketing (membangun reputasi politik). ${ }^{9}$ Senada dengan itu, Nurjaman (2014) mencoba ingin mengetahui cara partai-partai politik baru era Reformasi meraih suara dan bersaing dengan partai-partai mapan yang lebih dulu berpartisipasi pada pemilu-pemilu sebelumnya. Selain mengetahui cara partai baru mendapatkan suara, Nurjaman juga menganalisa tentang cara partai lama atau partai yang sudah mapan dalam mempertahankan basis massanya agar tidak pindah ke partai baru. $^{10}$

Sementara itu, Mahmud (2009) meneliti tentang strategi perbandingan kampanye yang dilakukan oleh PKPI dan PKS di mana kedua partai ini mengalami lonjakan suara yang signifikan pada Pemilu 2004 dibandingkan dengan Pemilu 1999. Pada Pemilu 2004 di Kota Salatiga, Jawa Tengah, suara PKPI meningkat hingga 784,8\%, sementara PKS juga mengalami peningkatan sebesar 555,5\%. ${ }^{11}$ Masih dalam konteks yang sama, Yutanti (2006) menelaah tentang pentingnya strategi kampanye yang dilakukan oleh lembaga kehumasan partai politik pada Pemilu 2004 khususnya di Kota Malang. Menurut Yutanti, dengan adanya humas, partai politik mampu menjembatani komunikasi politik secara efektif antara partai politik dengan pemilih meskipun penyebutan nama lembaga kehumasan di enam partai politik di Kota Malang berbeda-beda. $^{12}$

Berdasarkan sejumlah studi di atas, mayoritas penelitian mereka dilakukan pada Pemilu 2014 dan sebelumnya terutama yang berkaitan dengan isu komunikasi politik, pemasaran politik, strategi kampanye pemilihan presiden, dan strategi kampanye pemilu legislatif. Sementara itu, di bawah sistem pemilu proporsional terbuka yang berlaku di

9 Debora Sanur Lindawati, "Strategi Partai Politik Dalam Menghadapi Pemilu 2014" dalam Jurnal Politica, Vol. 4, No. 2 (2013), h. 287-312.

${ }^{10}$ Asep Nurjaman, "Party Survival: Strategi Meraih Kursi di Era Reformasi" dalam Jurnal Humanity, Vol. 9, No. 2 (2014), h. 12-24.

${ }^{11}$ Insan Mahmud, "Strategi Pemenangan Partai Keadilan dan Persatuan Indonesia (PKPI) dan Partai Keadilan Sejahtera (PKS) dalam Pemilu Legislatif Kota Salatiga Tahun 2009” dalam Politika: Jurnal Ilmu Politik, Vol. 9, No.1 (2018), h. 47-59.

12 Widya Yutanti, “Aktivitas dan Strategi Kehumasan Partai Politik Menjelang Pemilu 2004 (Studi pada Enam Partai Politik Besar di Kota Malang)" dalam HUMANITY, Vol. II, No. 1 (2006), h. 7685 . 
Indonesia sejak 2009, kajian spesifik yang menganalisa tentang keberhasilan partai politik dalam merebut kursi di parlemen tidak begitu menjadi kajian utama, sehingga belum ada kajian serius yang membedah keberhasilan partai politik dalam melakukan kampanye dan mengalami peningkatan suara yang sangat signifikan. Atas dasar itulah, artikel yang berbasis penelitian ilmiah ini konsen untuk membahas tentang strategi kampanye Nasdem pada Pemilu 2019.

\section{Mix Marketing sebagai Kerangka Teori}

Kajian ini menggunakan teori pemasaran bauran atau mix marketing untuk menganalisa strategi pemasaran Nasdem di Pemilu 2019. Mix marketing juga dikenal dengan sebutan 4P yaitu product, price, place, promotion. Pemilihan teori ini sebagai kerangka teori dalam menganalisa strategi kampanye Nasdem didasarkan pada beberapa alasan. Pertama, teori mix marketing sangat relevan untuk budaya politik di Indonesia di mana dengan menggunakan kerangka $4 \mathrm{P}$ tersebut, pembacaan terhadap strategi kampanye Nasdem dapat terungkap dengan jelas. Kedua, dibanding teori yang lain, teori mix marketing itu menggabungkan semua unsur yang ada dalam teori pemasaran sehingga teori ini tidak memisahkan antara produk dan cara pemasaran karena produk itu bagian dari pemasaran itu sendiri. Karena itu, metode pemasaran bauran ini sangat menarik dan mendalam dalam mengungkap strategi pemasaran partai politik. Ketiga, penjelasan teori mix marketing mudah dipahami oleh masyarakat umum dibanding teori pemasaran lainnya yang cenderung lebih bersifat isu bisnis dan manajemen. Berdasarkan ketiga alasan di atas itulah, penelitian ini menggunakan mix marketing sebagai kerangka teoritik penelitian ini.

Secara umum, pemasaran politik merupakan berbagai kegiatan yang dilakukan oleh kandidat dalam memasarkan muatan-muatan politik, seperti visi dan misi, ideologi, program dan identitas kontestan yang akan mengikuti pemilihan umum. Strategi pemasaran politik harus dilaksanakan dengan maksimal untuk mencapai tujuan. Pemasaran politik dilaksanakan dengan langkah strategis untuk menyampaikan berbagai muatan ide dan gagasan politik agar masyarakat tidak buta informasi politik. Rakyat akan semakin matang dalam mempertimbangkan, memutuskan dan menjatuhkan pilihan mereka pada hari pemungutan suara. Salah satu strategi pemasaran politik dilaksanakan dengan positioning politik yaitu semua aktivitas untuk menanamkan kesan dibenak 
konsumen agar mereka bisa membedakan produk dan jasa yang dihasilkan oleh organisasi. Menanamkan image dalam benak masyarakat tidak hanya terbatas pada produk dan jasa saja, karena organisasi perusahaan secara keseluruhan juga perlu ditambahkan dalam benak konsumen. ${ }^{13}$

Hal-hal seperti kredibilitas dan reputasi dapat digunakan sebagai media untuk melakukan positioning. Ketika konsep ini diadopsi dalam iklim persaingan kandidat harus mampu menempatkan produk politik dan image politik dalam benak masyarakat. untuk dapat tertanam, produk dan image politik harus memiliki sesuatu yang berbeda dibandingkan dengan produk politik lainnya. Strategi pemasaran politik dalam konteks penelitian ini adalah teori mix marketing yang mencakup empat indikator sebagai berikut. $^{14}$

Pertama, product (produk). Produk partai politik yang dijual adalah paltform, gagasan-gagasan, konsep-konsep, janji-janji yang memberikan harapan perbaikan nasib di masa mendatang, dan sebagainya. Jadi, sifatnya lebih abstrak, untuk platform, gagasan, konsep-konsep, janji-janji tersebut perlu dirinci dalam produk yang lebih spesifik dan praktis berupa program-program konkret. Kemudian dimasyarakatkan kepada kelompok sasaran melalui jalur komunikasi.

Kedua, promotion (promosi). Kegiatan promosi berkaitan dengan aktivitas partai politik dalam usaha menyebarkan informasi kepada seluruh anggota dan para simpatisannya. Promosi dalam pemasaran partai politik terdiri dari berbagai kegiatan komunikasi. Beberapa sarana yang dapat dipakai antara lain periklanan, sales promotion, publikasi, public relation.

Ketiga, price (harga). Pemahaman harga dalam konteks politik dapat dimodifikasi sebagai kemampuan dan kesediaan anggota partai dan konstituen dalam memberikan pengorbanan material dan beban psikologis untuk disumbangkan kepada partai. Makin tinggi kesediaan berkorban berarti partai politik memiliki harga yang kompetitif, artinya produk diminati walaupun dengan pemberian pengorbanan material dan immaterial bagi pendukungnya.

${ }^{13}$ Adman Nursal, Political Marketing: Strategi Memenangkan Pemilu Sebuah Pendekatan Baru Kampanye Pemilihan DPR, DPD, Presiden (Jakarta: PT Gramedia Pustaka, 2004).

${ }^{14}$ Firmanzah, Mengelola Partai Politik: Komunikasi dan Positioning Ideologi Politik Di Era Demokrasi (Jakarta: Yayasan Obor, 2008), h. 203. 
Keempat, place (tempat). Tempat dalam konteks politik dapat diartikan sebagai sarana kemudahan bagi para calon anggota, simpatisan dan anggota dalam memperoleh pelayanan informasi, transfer ide, pengorganisasian dan kehormatan politik praktis. Oleh karena itu kantor-kantor partai politik selalu berusaha didirikan dan disebar keberbagai tempat strategis sampai kepelosok kelurahan.

\section{Metode Penelitian}

Jenis penelitian adalah penelitian kualitatif. Penelitian kualitatif adalah penelitian yang dilakukan untuk memahami fenomena tentang apa yang dialami oleh subyek penelitian misalnya perilaku, persepsi, motivasi, tindakan dan lain sebagainya secara holistik dan dengan cara deskripsi dalam bentuk kata-kata serta bahasa pada suatu konteks khusus yang alamiah dan dengan memanfaatkan metode alamiah. ${ }^{15}$ Penelitian ini menggunakan pendekatan studi kasus (case study). Studi kasus merupakan jenis pendekatan untuk menyelidiki dan memahami suatu peristiwa atau masalah dengan cara mengumpulkan berbagai sumber informasi yang relevan kemudian diolah dan dianalisis untuk memperoleh jawaban serta solusi terkait permasalahan yang ada. Studi kasus penelitian ini ialah Nasdem pada Pemilu 2019.

Teknik pengumpulan data pada penelitian ini menggunakan teknik library research. Pada penelitin ini, peneliti akan mencari data-data yang diperlukan melalui pustaka yang tepat berdasarkan topik yang dibahas terutama berita-berita dari media online yang memiliki reputasi baik. Library research ialah suatu rangkaian kegiatan yang berhubungan dengan metode pengumpulan data pustaka, membaca dan mencatat serta mengolah bahan penelitian. Teknik yang digunakan untuk mengumpulkan data dalam penelitian ini adalah melalui berbagai sumber terpercaya, terutama dari media elektronik yang relevan dengan topik penelitian. Secara spesifik, penelitian ini akan berkonsentrasi pada berita pada media online yang ada kaitannya dengan Nasdem.

Teknik analisa data dalam penelitian ini melalui proses tiga tahap. Pertama, reduksi data. Data yang telah diperoleh dari media massa dipilah sesuai dengan tema yang dikaji sehingga sesuai dengan permasalahan yang ada. Kedua, penyajian data. Data akan disajikan secara sistematis sesuai dengan data yang telah direduksi

\footnotetext{
${ }^{15}$ Lexi J. Moleong, Metode Penelitian Kualitatif (Bandung: PT Remaja Rosdakarya, 2012), h. 6.
} 
sebelumnya. Ketiga, kesimpulan. Setelah dua tahap sebelumnya dilakukan, maka ditarik kesimpulan atas data-data yang telah ada dan juga dilakukan penarikan kesimpulan atas permasalahan yang diajukan sejak awal. ${ }^{16}$ Untuk memperkuat temuan, studi ini memanfaatkan aplikasi online wordcloud sebagai analisa penguat. Melalui wordcloud, susunan kata akan dimunculkan melalui sebuah sitem sebagai citra visual yang berkaitan dengan frekuensi kemunculan kata dalam suatu teks verbal. Visualisasi wordcloud dari teks akan mempermudah peneliti dalam melihat gagasan serta pendirian penulis teks sehingga mampu menjadi alat bantu untuk melakukan analisis terhadap sebuah wacana tertulis. Aplikasi online wordcloud juga berfungsi untuk melakukan analisis dari sebuah wacana tertulis. ${ }^{17}$ Citra visual yang ditampilkan memungkinkan peneliti untuk secara cepat dan praktis menangkap intisari penting dari data yang akan dianalisis. Dominasi visual yang muncul dalam citra wordcloud juga dapat memberikan informasi kepada peneliti tentang penekanan kata yang terlihat dari jumlah frekuensi pemakaian kata tertentu dalam suatu wacana tertulis.

\section{Hasil dan Pembahasan}

\section{Produk (Product)}

\section{a. Platform Partai: Politik Tanpa Mahar}

Nasdem sebagai partai yang baru dua kali berpartisipasi dalam Pemilu di Indonesia memperoleh suara yang besar jika dibandingkan partai-partai lain yang lebih dulu bepartisipasi dalam pemilu. Tren positif tersebut tidak lepas dari platform yang diusung oleh Nasdem. Nasdem memiliki slogan "Politik Tanpa Mahar" yang menjadi haluan politik di Indonesia. ${ }^{18}$ Gagasan tersebut muncul karena Nasdem mendengar keluh kesah masyarakat yang selalu mengidentikkan politik dengan uang.

Dikarenakan tingkat kepercayaan publik terhadap partai politik sangat rendah, yaitu hanya 35\% menurut hasil survei ICW (Indonesian Corruption Watch), maka Nasdem menerapkan startegi "Politik Tanpa Mahar" untuk mendobrak kelaziman politik transaksional. Hal ini dinilai positif karena partai tidak menaruh dukungan

${ }^{16}$ A. Muri Yusuf, Metode Penelitian: Kuantitatif, Kualitatif \& Penelitian Gabungan (Jakarta: Kencana, 2017), h. 407

${ }^{17}$ Carmel McNaught \& Paul Lam, "Using Wordle as a Supplementary Research Tool" dalam The Qualitative Report, Vol. 15, No. 3 (2010), h. 630-643.

${ }^{18}$ Candra Yuri Nuralam, "Cerita NasDem dan Politik Tanpa Mahar" dalam https://www .medcom.id/nasional/politik/lKYBLrjN-cerita-nasdem-dan-politik-tanpa-mahar diakses 1 Maret 2020. 
terhadap peserta pemilu berdasarkan takaran uang yang dimiliki, Nasdem berusaha agar membumikan gagasan tersebut meskipun ia rela kehilangan pendanaan sekitar 1 triliun rupiah pada Pilkada 2018. Akan tetapi strategi tersebut berhasil mengantarkan 11 kader/nonkader Nasdem menjadi Gubernur. ${ }^{19}$

Gebrakan Nasdem dalam mengkampanyekan "Politik Tanpa Mahar" dianggap ampuh dan partai politik lain patut mengikuti langkah Nasdem. Pengamat politik Universitas Indonesia, Donny Gahral Adian mengatakan sebagaimana dikutip oleh media online Warta Ekonomi, bahwa permasalahan korupsi tidak akan tuntas selama pembiayaan politik masih cukup tinggi. Artinya, para bakal calon legislatif (caleg) tidak perlu memikirkan dana besar jika ingin maju melalui Nasdem. Nantinya jika caleg tersebut terpilih, mereka tidak ada alasan untuk melakukan tindak pidana korupsi untuk mengembalikan modal politik ketika mereka mencalonkan diri menjadi anggota legislatif. ${ }^{20}$

Selain "Politik Tanpa Mahar", Nasdem juga membuat jargon "Nasdem Partaiku, Jokowi Presidenku". Nasdem memang salah satu partai yang mendukung Jokowi sebagai calon presiden 2019, dan Nasdem juga mendapatkan efek ekor jas dari Jokowi. Bahkan caleg Nasdem ada yang membuat baliho dengan bertuliskan jargon tersebut tepat di belakang foto caleg, padahal Jokowi bukan kader Nasdem melainkan kader PDI-P. ${ }^{21}$ Sepertinya, platform "Politik Tanpa Mahar" cukup berhasil dalam mengantarkan Nasdem sebagai lima partai besar pada Pemilu 2019 di saat isu politik mahar menjadi momok tersendiri bagi para caleg dan menjadi kesempatan bagi partai politik untuk mencari keuntungan dari setiap momen pemilu.

\section{b. Past Record}

Nasdem pertamakali berpartisipasi dalam Pemilu 2014. Menariknya, Nasdem merupakan satu-satunya partai baru yang lolos verifikasi untuk mengikuti Pemilu 2014.

19 Sobih AW. Adnan, "Membumikan Gagasan Politik Tanpa Mahar" dalam https://www.medcom.id/pilar/fokus/aNrDZ12k-membumikan-gagasan-politik-tanpa-mahar diakses 3 Maret 2020.

${ }^{20}$ Redaksi WE Online, "Politik Tanpa Mahar NasDem Positif? Ini Kata Pengamat" dalam https://www.wartaekonomi.co.id/read214409/politik-tanpa-mahar-nasdem-positif-ini-kata-pengamat.html diakses 2 Maret 2020.

21 Kurnia Sari Aziza, "Resmi, Nasdem Dukung Pencapresan Jokowi” dalam https://nasional.kompas.com/read/2014/04/12/1322388/Resmi.Nasdem.Dukung.Pencapresan.Jokowi diakses 4 Maret 2020. 
Meskipun saat itu Nasdem belum memiliki basis massa yang kuat, akan tetapi Nasdem menargetkan tiga besar dalam Pemilu 2014, dengan tujuan ingin mengusung capres sendiri. Sebagai partai baru, Nasdem tidak main-main dalam mengikuti Pemilu 2014, hal ini dibuktikan dengan Nasdem tidak meminta biaya pendaftaran kepada caleg, Nasdem juga melamar orang-orang potensial yang punya kemampuan politik untuk dijadikan kader partai dan membuka sekolah legislatif. $^{22}$

Nasdem sebagai pendatang baru pada Pemilu 2014 benar-benar beruntung, selain satu-satunya partai baru yang lolos verifikasi, Nasdem juga mendapatkan Nomor Urut 1 sebagai partai peserta Pemilu 2014. Dalam menghadapi Pemilu 2014 Nasdem merangkul semua lapisan masyarakat, tidak memandang ras, suku dan agama. Meskipun jalan yang ditempuh Nasdem terlihat 'mulus', Nasdem juga sempat diterpah perpecahan diinternal partai sesaat setelah kongres partai atau setahun sebelum Pemilu 2014 dilaksanakan. Konflik tersebut terkait rivalitas antara Harry Tanoe dan Surya Paloh dalam kubuh Nasdem. ${ }^{23}$

Akibat perpecahan tersebut, Harry Tanoe mundur dari Nasdem. Harry Tanoe mundur dikarenakan adanya konflik kepentingan dengan Surya Paloh, kedua tokoh itu berebut untuk menjadi Ketua Umum Nasdem dalam mengarungi Pemilu 2014. Meskipun dengan keluarnya Harry Tanoe dari Nasdem tidak berdampak serius terhadap kinerja para kader partai untuk menghadapi pemilu yang sudah di depan mata, karena lebih banyak kader yang mendukung Surya Paloh jika dibandingkan dengan Harry Tanoe. Selain Harry Tanoe, sekjen Nasdem Ahmad Rofiq dan wakilnya Saiful Haq pada waktu itu juga mengundurkan diri dan beberapa DPW yang berada di berbagai provinsi, Sri Sultan Hamengku bowono X juga mundur karena Organisasi Masyarakat Nasdem telah berubah menjadi partai politik. ${ }^{24}$

Pada Pemilu 2014, Nasdem berhasil menduduki peringkat delapan dengan persentase suara 6,72\%. Meskipun melenceng dari target awal yaitu tiga besar, pencapaian Nasdem di Pemilu 2014 sudah luar biasa mengingat Nasdem merupakan partai baru dan pertamakali mengikuti pemilu. Nasdem selalu konsisten mendukung

\footnotetext{
${ }^{22}$ Detik.com, "NasDem Kejar 3 Besar Di Pemilu 2014" dalam https://news.detik.com/berita/d2183789/nasdem-kejar-3-besar-di-pemilu-2014 diakses 1 Maret 2020.

23 Riski Adam, "Partai Nasdem Akui Konflik Internal" dalam https://www.liputan6. com/news/read/487148/partai-nasdem-akui-konflik-internal diakses 2 Maret 2020.

${ }^{24}$ Yunicha Diana \& Robi Cahyadi Kurniawan "Konflik Internal Partai NasDem Dan Pemilihan Legislatif 2014" dalam Jurnal Wacana Politik, Vol. 1, No. 1 (2016), h. 22-28.
} 
Jokowi sebagai calon Presiden, tidak hanya Pemilu 2019, pada Pemilu 2014 Nasdem juga telah mendukung Jokowi sebagai calon Presiden. Salah satu alasan Nasdem berkoalisi dengan PDI-P dalam menungusung Jokowi sebagai calon Presiden, karena Nasdem menganggap platform Nasdem yaitu Restorasi Indonesia segaris dengan tagline PDI-P yaitu "Menuju Indonesia Hebat". ${ }^{25}$

Untuk tingkat tindak pidana korupsi, anggota DPR dari Nasdem tergolong kecil yang menjadi tersangka jika dibandingkan partai-partai lainnya. Menurut data yang dirilis oleh Indonesia Corruption Watch (ICW), Nasdem merupakan salah satu partai politik dengan kasus tindak pidana korupsi paling rendah dibanding dengan partai-partai yang lainnya. Ketika Nasdem hanya ada satu kasus, partai lain mempunyai kasus yang banyak seperti Golkar dengan delapan kasus. Sementara, PDI-P, Demokrat dan PAN masing-masing dari mereka mempunyai tiga kasus korupsi. Anggota DPR dari Nasdem yang berkasus yaitu Patrice Rio Capella, anggota Komisi III DPR RI. Menariknya, Patrice adalah salah satu pendiri Nasdem. ${ }^{26}$ Lolosnya Nasdem pada pemilu 2014 menuju Senayan menjadi tiket baginya untuk menjadi salah satu partai kuat pendukung Jokowi-JK saat itu sehingga Nasdem meraih efek ekor jas (cottail-effect) pada pemilu 2019.

\section{c. Karakteristik Personal}

Parameter utama yang digunakan untuk mengukur karakteristik personal adalah latar belakang para caleg Nasdem yang bertarung pada Pemilu 2019 terutama caleg yang maju ke tingkat DPR RI. Pada Pemilu 2019, ada 575 kursi DPR RI di 80 daerah pemilihan (Dapil) seluruh Indonesia yang diperebutkan oleh masing-masing partai peserta pemilu. Sedangkan, Nasdem memiliki 575 caleg yang akan bertarung memberbutkan kursi legislatif DPR RI. Artinya, Nasdem maju dengan caleg yang sama jumlahnya dengan kursi yang tersedia di Senayan, hal ini membuat Nasdem berperluang untuk mendapatkan banyak kursi di parlemen karena hampir memenuhi ketersedian kursi di setiap Dapil. Dari 575 caleg tersebut, penulis akan gambarkan secara rinci latar

${ }^{25}$ Fitria Chusna Farisa, "Ini Hasil Lengkap Pemilu Legislatif 2019 yang Ditetapkan KPU” dalam https://nasional.kompas.com/read/2019/05/21/05000061/ini-hasil-lengkap-pemilu-legislatif-2019-yangditetapkan-kpu diakses 3 Maret 2020.

26 CNN Indonesia, "infografis: daftar anggota dpr 2014-2019 terjerat korupsi” dalam https://www.cnnindonesia.com/nasional/20190919085039-35-431798/infografis-daftar-anggota-dpr2014-2019-terjerat-korupsi diakses 3 Maret 2020. 
belakang mereka meliputi jenis kelamin, agama, pendidikan, pekerjaan, umur, status perkawinan dan agama.

Gambar 1

Jenis Kelamin Caleg Nasdem untuk DPR RI pada Pileg 2019 (\%)

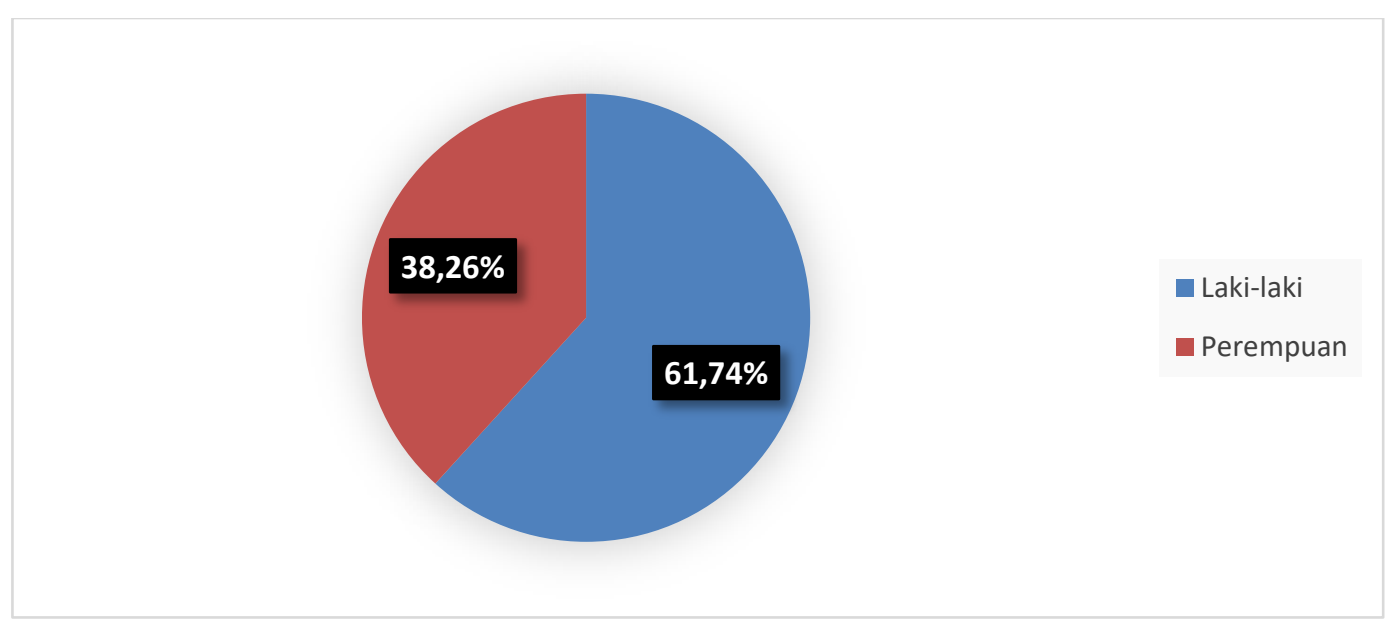

Sumber: Diolah Dari Data KPU RI (2019)

Gambar 1 menunjukkan bahwa caleg perempuan secara persentase melebihi kuota yang telah ditetapkan oleh undang-undang yaitu 30\%. Pemilu 2019, Nasdem mencalonkan $38,26 \%$ perempuan atau 220 orang, sedangkan caleg laki-laki $61,74 \%$ atau 355 orang.

Gambar 2

Tingkat Pendidikan Caleg Nasdem untuk DPR RI pada Pileg 2019 (\%)

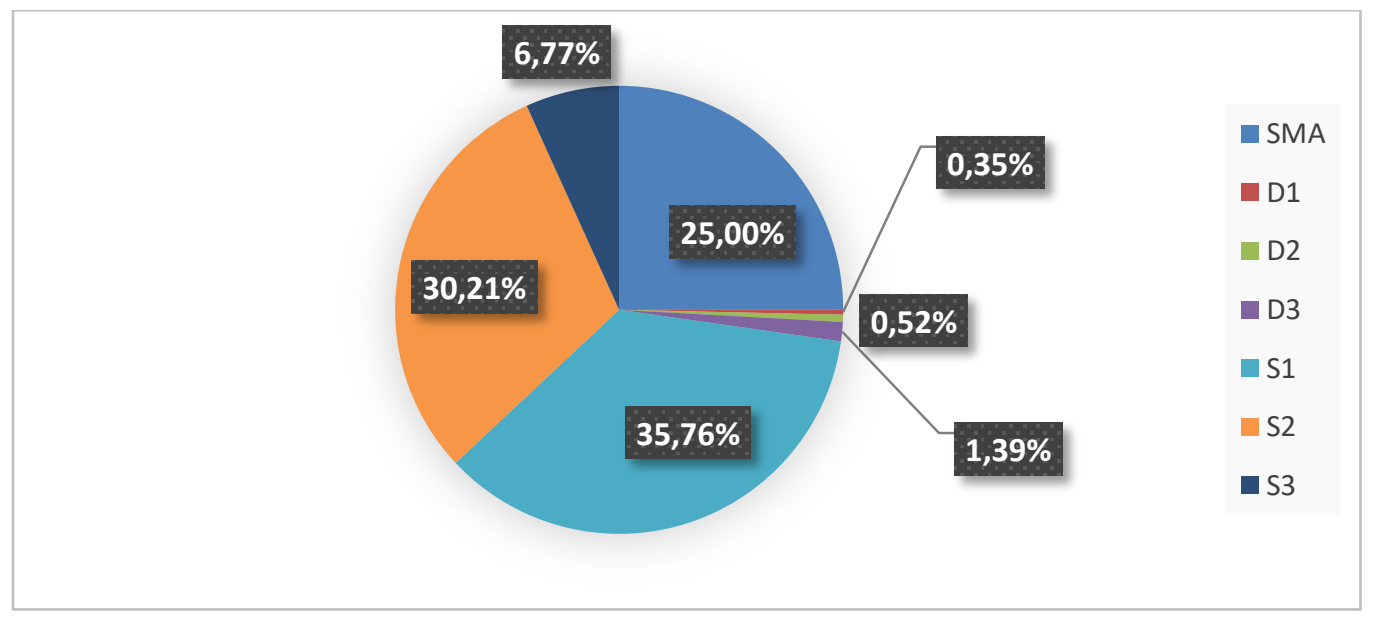

Sumber: Diolah dari Data KPU RI (2019) 
Gambar 2 menunjukkan bahwa mayoritas caleg Nasdem untuk DPR RI adalah lulusan S1 sebanyak 35,76\% atau 206 orang. Kemudian disusul lulusan S2 sebanyak $30,21 \%$ atau 174 orang. Sementara lulusan SMA 25\% dan lulusan S3 sebanyak 6,77\%. Terendah adalah lulusan D1, D2 dan D3 masing-masing berjumlah 1\% dan 0\%. Jika dilihat dari data di atas, caleg Nasdem berdasarkan tingkat pendidikan didominasi oleh orang-orang yang berpendidikan tinggi.

Tabel 1

Latar Belakang Profesi Caleg Partai Nasdem 2019

\begin{tabular}{|c|l|r|r|}
\hline No. & \multicolumn{1}{|c|}{ Latar Belakang Caleg } & Jumlah & \% \\
\hline 1 & Pengusaha/Pekerja Swasta/wiraswasta & 315 & $54,78 \%$ \\
\hline 2 & Petahana/Mantan anggota DPR/DPRD & 66 & $11,48 \%$ \\
\hline 3 & Artis/Entertaint & 45 & $7,83 \%$ \\
\hline 4 & Akademisi: Dosen, Peniliti, Guru & 26 & $4,52 \%$ \\
\hline 5 & Pensiunan PNS & 26 & $4,52 \%$ \\
\hline 6 & Mantan Pejabat Lembaga Eksekutif & 21 & $3,65 \%$ \\
\hline 7 & Profesi Hukum: Advokat, Notaris, Kons. Hukum & 20 & $3,48 \%$ \\
\hline 8 & IRT (Ibu Rumah Tangga) & 15 & $2,61 \%$ \\
\hline 9 & Dokter & 11 & $1,91 \%$ \\
\hline 10 & Mahasiswa & 10 & $1,74 \%$ \\
\hline 11 & Militer: TNI-Polri & 6 & $1,04 \%$ \\
\hline 12 & Staf/Tenaga Ahli Lembaga Legislatif/Eksekutif & 5 & $0,87 \%$ \\
\hline 13 & Konsultan & 4 & $0,70 \%$ \\
\hline 14 & Aktifis Partai Politik & 3 & $0,52 \%$ \\
\hline 15 & Jurnalis & 2 & $0,35 \%$ \\
\hline \multicolumn{2}{|c|}{ Total } & $\mathbf{5 7 5}$ & $\mathbf{1 0 0 \%}$ \\
\hline
\end{tabular}

Sumber: Diolah dari data KPU RI (2019)

Tabel 1 menunjukkan bahwa mayoritas caleg Nasdem memiliki latar belakang pekerja swasta dan pengusaha dari berbagai sektor yang berbeda-beda. Dari data yang dihimpun penulis, dari 80 Dapil di seluruh Indonesia ada caleg yang berlatar belakang pengusaha, bahkan caleg Nasdem di Dapil Jateng 2 dan Dapil Gorontalo semuanya berlatar belakang pengusaha. Terbanyak kedua setelah caleg yang berprofesi pengusaha adalah caleg yang berprofesi sebagai anggota DPR/DPRD periode 2014-2019 yang berjumlah 69 orang, kemudian disusul oleh caleg yang berlatar belakang akademisi yang berjumlah 26 orang. Dari sini dapat diketahui, bahwa mayoritas para caleg Nasdem memiliki latar belakang pendidikan yang baik karena lebih dari dari $70 \%$ merupakan lulusan perguruan tinggi. Profil tersebut diperkuat lagi dengan latar 
belakang mereka dari mayoritas kalangan pengusaha dan para artis di mana Nasdem adalah partai dengan caleg artis terbanyak di Pemilu 2019.

Pada Pemilu 2019, Nasdem banyak mencalonkan nama yang berpotensi meraih massa yang banyak. Ada menteri perdagangan era 2014-2015, Rachmat Gobel, mantan menteri pemuda dan olahraga era Soeharto, Hayono Isman, selain itu banyak juga mantan Gubernur di sejumlah daerah dan para artis banyak di calonkan oleh Nasdem. Nasdem mengakui melalui Johnny G. Plate bahwa Nasdem merekrut nama-nama beken demi meraup suara yang banyak. ${ }^{27}$

Nasdem juga mengklaim tidak ada caleg Nasdem yang berasal dari pejabat eksekutif yang aktif dalam pemerintahan, karena semua berkonsentrasi dalam memenangkan Pemilihan Presiden 2019. Adapun caleg pejabat eksekutif akan tetapi tidak aktif atau mantan kepala daerah. Dalam data Nasdem hanya mencalonkan orangorang yang mayoritas berprofesi sebagai pengusaha, artis dan mantan pejabat eksektuif. $^{28}$ Berikut adalah Tabel 2 yang menggambarkan latar belakang profesi artis/selebritis dari Nasdem yang maju di pemilihan legislatif DPR RI.

Tabel 2

Latar Belakang Profesi Caleg Artis dari Partai Nasdem

\begin{tabular}{|c|l|c|l|l|}
\hline No. & \multicolumn{1}{|c|}{ Nama Caleg } & $\begin{array}{c}\text { Jenis } \\
\text { Kelamin }\end{array}$ & \multicolumn{1}{|c|}{ Profesi } & \multicolumn{1}{|c|}{ Dapil } \\
\hline 1 & Puji Chegana & P & Freelance Model & Sumbar 1 \\
\hline 2 & Vivien Suwito & P & MC & Riau 1 \\
\hline 3 & Septian W & L & Pemain Sinetron & Lampung1 \\
\hline 4 & Wanda Hamidah & P & Penyayi/Notaris & DKI 1 \\
\hline 5 & Okky Asokawati & P & DPR RI 2014-2019/Model & DKI 2 \\
\hline 6 & M Farhan & L & Presenter & Jabar 1 \\
\hline 7 & Citra Skolastika & P & Penyanyi & Jabar 1 \\
\hline 8 & Ade Irma & L & Penyanyi & Jabar 1 \\
\hline 9 & Moh Arif S & L & $\begin{array}{l}\text { DPR RI 2014-2019 } \\
\text { Presenter }\end{array}$ & Jabar 1 \\
\hline 10 & Tina Talisa & P & Presenter & Jabar 2 \\
\hline
\end{tabular}

${ }^{27}$ Budiarti Utami Putri, "Deretan Caleg Partai NasDem, dari Bekas Menteri Hingga Artis" dalam https://nasional.tempo.co/read/1107986/deretan-caleg-partai-nasdem-dari-bekas-menteri-hingga-artis diakses 1 Maret 2020.

${ }^{28}$ Lina Herlina, "Resmi Gabung NasDem, Gubernur Sulsel Ikut Safari Politik Surya Paloh" dalam https://mediaindonesia.com/read/detail/150489-resmi-gabung-nasdem-gubernur-sulsel-ikut-safaripolitik-surya-paloh diakses 3 Maret 2020. 


\begin{tabular}{|c|c|c|c|c|}
\hline 11 & Olla Ramlan & $\mathrm{P}$ & Presenter & Jabar 4 \\
\hline 12 & Sahrul Gunawan & $\mathrm{L}$ & Pemain sinetron & Jabar 5 \\
\hline 13 & Citra Anggun & $\mathrm{P}$ & Pemain Sinetron/penyanyi & Jabar 5 \\
\hline 14 & Lucky Hakim & $\mathrm{L}$ & Aktor & Jabar 6 \\
\hline 15 & $\begin{array}{l}\text { Fivey } \\
\text { Rachmawati }\end{array}$ & $\mathrm{L}$ & Pesinetron/pemain film & Jabar 6 \\
\hline 16 & Della Puspita & $\mathrm{P}$ & Pesinetron/Penyanyi & Jabar 7 \\
\hline 17 & Nurul Qomar & $\mathrm{L}$ & Pelawak/Dosen & Jabar 8 \\
\hline 18 & Diana Sastra & $\mathrm{P}$ & Penyanyi Dangdut & Jabar 8 \\
\hline 19 & Krisna Mukti & $\mathrm{L}$ & DPR RI 2014-2019/aktor & Jabar 10 \\
\hline 20 & Selfi Nafila & $\mathrm{P}$ & Penyanyi Dangdut & Jabar 10 \\
\hline 21 & Cut Meyriska & $\mathrm{P}$ & Model/Penyanyi & Jateng 1 \\
\hline 22 & Adly Fayrus & $\mathrm{L}$ & Penyanyi & Jateng 1 \\
\hline 23 & Kartika A & $\mathrm{P}$ & Pemain Sinetron & Jateng 1 \\
\hline 24 & Helena Andrian & $\mathrm{P}$ & Penyanyi & Jateng 4 \\
\hline 25 & Afdhal & $\mathrm{L}$ & Aktor & Jateng 4 \\
\hline 26 & Livy Andiani & $\mathrm{P}$ & Model/Penyanyi & Jateng 4 \\
\hline 27 & Bertrand Antolin & $\mathrm{L}$ & Aktor & Jateng 5 \\
\hline 28 & Miranda Vera & $\mathrm{P}$ & Model & Jateng 5 \\
\hline 29 & Nafa Urbach & $\mathrm{P}$ & Pemain film/penyanyi & Jateng 6 \\
\hline 30 & Ageng Wahono & $\mathrm{L}$ & Penyanyi & Jateng 8 \\
\hline 31 & Chris John & $\mathrm{L}$ & Artis/Atlit & Jateng 9 \\
\hline 32 & Anisa Bahar & $\mathrm{P}$ & Penyanyi & Jateng 9 \\
\hline 33 & Syivia Fuly & $\mathrm{P}$ & Pemain Film & Jateng 9 \\
\hline 34 & Jonathan & $\mathrm{L}$ & Pemain sinetron & Jateng 10 \\
\hline 35 & Kristina & $\mathrm{P}$ & Penyanyi Dangdut & Jateng 10 \\
\hline 36 & Manohara & $\mathrm{P}$ & Model/Penyanyi & Jatim 1 \\
\hline 37 & Rachma Sarita & $\mathrm{P}$ & Penyiar TV & Jatim 2 \\
\hline 38 & Lucky Perdana & $\mathrm{L}$ & Aktor & Jatim 3 \\
\hline 39 & Yuli Anita & $\mathrm{P}$ & Penyanyi Dangdut & Jatim 3 \\
\hline 40 & Imelda Soraya & $\mathrm{P}$ & Pemain film/model & Jatim 4 \\
\hline 41 & Venna Melinda & $\mathrm{P}$ & DPR RI 2014-2019/model & Jatim 6 \\
\hline 42 & Ratna Sulis & $\mathrm{P}$ & Penyanyi/pemain sinetron & Jatim 8 \\
\hline 43 & Tessa Kaunang & $\mathrm{P}$ & Presenter/model & Jatim 9 \\
\hline 44 & Elma Theana & $\mathrm{P}$ & Aktris/bintang iklan & Jatim 10 \\
\hline 45 & Gusti Rosalina & $\mathrm{P}$ & Model/Penyanyi & Kalsel 1 \\
\hline
\end{tabular}

Tabel 2 menunjukkan bahwa caleg artis dari Nasdem mayoritas berjenis kelamin perempuan yang berjumlah 28 orang, sedangkan caleg artis yang berjenis kelamin lakilaki sebanyak 15 orang. Dari segi latar belakang profesi juga berbeda-beda akan tetapi 
profesi penyanyi dan pemain sinetron yang mendominasi. Ada juga dari mereka yang maju sebagai petahana. Mayoritas artis mencalonkan diri sebagai caleg di Dapil yang berada di pulau Jawa, Cuma ada satu artis yang mencalonkan sebagai caleg di luar pulau Jawa yaitu Gusti Rosalina dari Dapil Kalsel 1. Dari 45 caleg artis dari Nasdem, hanya satu yang lolos yaitu Muhammad Farhan dari Dapil Jabar 1. Ini artinya, bahwa Nasdem mengandalkan caleg berlatarbelakang artis sebagai pengepul suara (vote getter) sehingga suara Nasdem memang mengalami peningkatan suara paling besar dibanding partai politik yang lainnya. Meskipun para artis tersebut tidak banyak yang lolos ke Senayan, setidaknya suara mereka mampu mendongkrak perolehan suara Nasdem secara nasional yang menjadikan Nasdem sebagai lima partai besar pada Pemilu 2019.

Kategori umur para caleg Nasdem untuk DPR RI 2019, di dominasi oleh kelompok umur 51-60 tahun, dan yang paling sedikit adalah kelompok umur di bawah 25 tahun. Nasdem memang tidak banyak mencalonkan para milenial, padahal pemilih di 2019 mayoritas kaum milenial atau pemilih-pemilih yang di bawah 25 tahun. Status perkawinan caleg Nasdem untuk DPR RI, mayoritas sudah menikah dengan persentase $82,26 \%$ dan belum menikah sebanyak $10,61 \%$, sedangkan yang pernah menikah atau duda dan janda sebanyak $7,13 \%$. Tidak ada perbedaan yang signifikan antara calon yang belum menikah dengan calon yang pernah menikah. Sedangkan untuk agama caleg Nasdem DPR RI 2019, mayoritas bergama Islam, mengingat Indonesia adalah negara dengan penduduk mayoritas memeluk agama Islam, sedangkan yang paling kecil persentasenya adalah agama Budha dengan $0,35 \%$ atau hanya dua orang yang menganut agama Budha.

\section{Harga (Price)}

\section{a. Harga Ekonomi}

Partai Politik yang berpartisipasi dalam Pemilu 2019 harus melaporkan penerimaan dan pengeluaran dana kampanye ke KPU RI dengan tujuan sebagai bentuk pertanggung jawaban partai politik kepada publik. Nasdem menyerahkan Laporan Penerimaan dan Pengeluaran Dana Kampanye (LPPDK) ke KPU RI, LPPDK Nasdem sebesar Rp. 259.474.071.714 dengan rincian $\mathrm{Rp}$ 80.610.513.963 atau berasal dari partai, 
sedangkan Rp. 177.863.557.751 berasal dari sumbangan para caleg, dan Rp. 1 miliar berasal dari sumbangan pihak lain badan non usaha pemerintah. ${ }^{29}$

Dari 575 caleg Nasdem yang maju, Nasdem hanya mendapatkan 59 kursi, 18 di antaranya adalah petahana. Penyumbang dana kampanye terbesar adalah Ahmad Ali dari Dapil Sulteng 1 yang menyumbang Rp. 5,9 miliar, sementara penyumbang dana kampanye paling kecil adalah Muhammad Farhan dari Jabar 1 yang menyumbang Rp. 30,9 juta, walapun ada beberapa caleg yang lolos tidak diketahui nominal dana yang mereka sumbangkan.

Besaran dana tersebut bukan total biaya yang dikeluarkan para caleg untuk maju ke Senayan, karena itu cuma sumbangan mereka ke partai. Partai membuka rekening untuk menerima sumbangan dari caleg dan sumbangan tersebut nantinya akan digunakan untuk keperluan selama kampanye partai dan untuk membantu beberapa caleg. Para caleg harus bergerilya setiap hari demi meraup suara yang banyak, dan itu membutuhkan dana yang tidak sedikit. Hal ini juga dikatakan oleh bendahara umum Nasdem yang juga caleg DPR RI, Ahmad Hi Ali. ${ }^{30}$ Hal ini menunjukkan, bahwa biaya kampanye yang dikeluarkan oleh Nasdem sangatlah besar karena dana yang dilaporkan tersebut tentu ditambah dana lain yang digunakan tetapi belum sempat dilaporkan.

\section{b. Harga Psikologis}

Harga psikologis membahas tentang strategi caleg Nasdem di Dapil di mana Nasdem peringkat satu di antara partai-partai lainnya. Masing-masing caleg Nasdem tentu memiliki cara mendekati pemilihnya, salah satunya membuat psikologi pemilih merasa nyaman untuk memberikan suaranya pada caleg yang diinginkan.

Berdasarkan profil caleg Nasdem yang telah jelaskan di awal, hasil Pemilu 2019 menunjukkan bahwa perolehan suara Nasdem unggul di lima Dapil dari 80 Dapil secara nasional. Kelima Dapil berada di bagian Indonesia Timur, Nasdem merekrut namanama beken yang dulunya adalah kepala daerah di Dapil tersebut.

\footnotetext{
${ }^{29}$ Data LPPDK Bawaslu, 2019.

30 Thomas Harming Suwarta, "NasDem Laporkan Dana Kampanye Rp259 Miliar Ke KPU" dalam https://mediaindonesia.com/read/detail/238895-nasdem-laporkan-dana-kampanye-rp259-miliar-ke-kpu diakses 1 Maret 2020.
} 
Tabel 3

Profesi Caleg Nasdem di mana Nasdem Unggul di Empat Dapil

\begin{tabular}{|c|c|c|c|c|}
\hline \multirow{2}{*}{ No. } & \multirow{2}{*}{ Nama Dapil } & \multicolumn{2}{|c|}{$\begin{array}{c}\text { Perbandingan } \\
\text { Besaran Kursi dan } \\
\text { Jumlah Caleg Nasdem }\end{array}$} & \multirow{2}{*}{ Latar Belakang Caleg } \\
\hline & & $\begin{array}{c}\text { Besaran } \\
\text { Kursi di } \\
\text { Dapil }\end{array}$ & $\begin{array}{l}\text { Jumlah } \\
\text { Caleg } \\
\text { Nasdem }\end{array}$ & \\
\hline 1 & NTT 2 & 7 & 7 & $\begin{array}{l}3 \text { Anggota DPR } \\
1 \text { Dokter } \\
3 \text { Pengusaha }\end{array}$ \\
\hline 2 & PAPUA & 10 & 10 & $\begin{array}{l}4 \text { Pengusaha } \\
3 \text { Anggota DPR } \\
1 \text { Pastur } \\
2 \text { Pensiunan Dosen }\end{array}$ \\
\hline 3 & $\begin{array}{l}\text { PAPUA } \\
\text { BARAT }\end{array}$ & 3 & 3 & 3 Pengusaha \\
\hline 4 & SULSEL 3 & 7 & 7 & $\begin{array}{l}3 \text { Pengusaha } \\
1 \text { Dokter } \\
1 \text { Mantan Bupati } \\
1 \text { Anggota DPR } \\
1 \text { Tenaga Ahli DPR } \\
\end{array}$ \\
\hline 5 & SULTENG & 7 & 7 & $\begin{array}{l}3 \text { Pengusaha } \\
1 \text { Mantan Walikota } \\
1 \text { Anggota DPR } \\
1 \text { Notaris } \\
1 \text { Konsultan dan Dosen } \\
\text { Swasta }\end{array}$ \\
\hline
\end{tabular}

Sumber: Diolah dari data KPU RI (2019)

Secara lebih rinci, tabel menggambarkan bahwa Nasdem perkasa di lima Dapil tersebut. Di Dapil Papua, Nasdem berhasil mendapatkan 3 Kursi sekaligus.

Tabel 4

Suara Caleg Nasdem Terpilih di Lima Dapil (Unggul)

\begin{tabular}{|c|l|c|l|}
\hline No. & Nama Dapil & $\begin{array}{c}\text { Suara Sah } \\
\text { Nasdem }\end{array}$ & \multicolumn{1}{|c|}{ Caleg Terpilih } \\
\hline 1 & NTT 2 & $291,761(22 \%)$ & $\begin{array}{l}\text { Kristiana Muki/66,173 suara } \\
\text { Ratu Ngadu Wulla/50,545 suara }\end{array}$ \\
\hline 2 & PAPUA & $544,854(25 \%)$ & $\begin{array}{l}\text { Roberth Rouw/274,426 suara } \\
\text { Sulaiman Hamzah/161,898 suara } \\
\text { Ina Kobak/118,421 suara }\end{array}$ \\
\hline
\end{tabular}




\begin{tabular}{|c|l|l|l|}
\hline 3 & $\begin{array}{l}\text { PAPUA } \\
\text { BARAT }\end{array}$ & $85,193(19 \%)$ & Rico Sia/50,415 suara \\
\hline 4 & SULSEL 3 & $259,751(19 \%)$ & $\begin{array}{l}\text { Rusdi Masse (119,003 suara) } \\
\text { Eva Rataba (44,240 suara) }\end{array}$ \\
\hline 5 & SULTENG & $266,549(17 \%)$ & Ahmad Ali (152,270 suara) \\
\hline
\end{tabular}

Keunggulan suara Nasdem di lima Dapil tersebut tidak bisa dilepaskan dari peran para caleg di dalamnya, terutama dalam hal kampanye politik. Tentu, peran dari para caleg tersebut adalah baik caleg yang terpilih lolos ke Senayan maupun yang tidak lolos karena mereka bersama-sama mengangkat posisi Nasdem ke urutan teratas di Dapil tersebut. Secara lebih detail, penulis akan ungkap pengalaman kampanye beberapa caleg yan terpilih dari lima Dapil tersebut.

Kristiana Muki dan Ratu Wulla misalnya, mereka adalah istri Bupati yang bertarung di Dapil NTT 2 dan keduanya lolos ke Senayan. Kritiana Muki adalah istri Bupati Timor Tengah Utara yaitu Raymundus Sau Fernandes, sedangkan Ratu Wulla merupakan istri Bupati Sumba Barat Daya yaitu Marku Dairu Talu. Meski diuntungkan karena kepopulerannya sebagai istri Bupati, Kristiana Muki tetap bergerilya demi mendapatkan simpati warga. ${ }^{31}$

Dari Dapil Papua, Nasdem berhasil mendapatkan tiga kursi untuk ke Senayan ketiga caleg tersebut adalah Robert Rouw, Sulaiman Hamzah dan Ina Elisabeth Kobak. Robert Rouw dan Sulaiman Hamzah adalah caleg petahana. Robert Rouw yang dulunya adalah kader Gerindra kemudian maju kembali untuk menjadi caleg bersama Nasdem, Robert Rouw berhasil mendapatkan perolehan suara terbanyak yaitu 274,426 suara. Robert Rouw pantas jika mendapatkan suara terbanyak, melihat rekam jejaknya yang mati-matian memperjuangkan rakyat Papua, salah satunya dalam memperjuangkan rumah sakit di daerah pegunungan Papua, Wamena. ${ }^{32}$

31 Tommy Mbenu Nulangi, "Kristina Muki Target Perolehan 100.000 Lebih Suara" dalam https://kupang.tribunnews.com/2019/04/12/kristina-muki-target-perolehan-100000-lebih-suara diakses 1 Maret 2020.

${ }^{32}$ Beritasatu.com, "Roberth Rouw Raih Suara Terbanyak Caleg DPR dari Papua" dalam https://www.beritasatu.com/politik/555060/roberth-rouw-raih-suara-terbanyak-caleg-dpr-dari-papua dikases 2 Maret 2020. 
Tidak hanya Roberth Rouw, Sulaiman Hamzah juga memenang di Dapil Papua. Sulaiman Hamzah sering "blusukan" ke distrik-distrik yang ada di Dapilnya untuk mensosialisasikan program-program yang akan dijalankan ketika terpilih kembali menjadi anggota DPR. Sulaiman Hamzah juga memimpin kampanye akbar Nasdem di Tolikara yang dihadiri ribuan masyarakat Tolikara. ${ }^{33}$

Selain kedua nama senior tersebut, ada juga Ina Elisabeth Kobak yang berhasil lolos ke Senayan. Putri Wamena yang masih berusia 29 tahun tersebut melengkapi daftar milenial yang lolos ke Senayan di Pemilu 2019. Ina punya perhatian khusus pada pendidikan anak usia dini, kesehatan balita, ibu hamil dan juga lansia. ${ }^{34}$

Sedangkan kandidat caleg dari Dapil Sulawesi Selatan 3, Rusdi Masse melakukan kampanye dengan cara tatap muka langsung dengan masyarakat dan menggaet tokoh masyarakat yang berada di Dapilnya. Masyarakat juga sangat mendukung dan optimis Rusdi Masse terpilih, karena sebelumnya Rusdi Masse sudah menjadi Bupati dua periode di Kab. Sidrap, tidak hanya masyarakat Sidrap, masyarakat Kab. Pinrang juga banyak yang menunjukkan rasa optimisnya ke Rusdi Masse, seperti yang diungkapkan tokoh masyarakat Pinrang, H. Gani. ${ }^{35}$

Selain Rusdi Masse, Eva Rataba juga caleg dari Dapil Sulsel Selatan 3 yang berhasil lolos ke Senayan. Eva Rataba merupakan caleg wanita yang juga aktif sebagai Ketua Garnita Malahayati Toraja Utara, juga aktif di PKK Toraja Utara, dan Ketua Himpunan Pendidik Dan Tenaga Pendidik Anak Usia Dini Indonesia (Himpaudi). Eva memokuskan untuk memajukan pariwisata dan pendidikan di Dapil Sulsel 3 terutama di Toraja Utara.

Di Dapil Sulawesi Tengah, Nasdem berhasil merebut satu kursi melalui Ahmad Ali yang merupakan tokoh senior di Sulteng. Ahmad Ali terpilih kembali sebagai anggota DPR bersama Nasdem dengan perolehan suara 152,270 suara. Ahmad Ali juga tercata sebagai penyumbang kampanye terbesar di Nasdem pada Pemilu 2019, Ahmad

\footnotetext{
${ }^{33}$ Papuasatu.com, "Kemenangan Partai NasDem Akan Dimulai Dari Kabupaten Tolikara" dalam https://papuasatu.com/polhukrim/kemenangan-partai-nasdem-akan-dimulai-dari-kabupaten-tolikara/ diakses 1 Maret 2020.

${ }^{34}$ Siti Ruqoyah \& Lilis Khalisotussurur, "Sederet Milenial yang Jadi Anggota DPR" dalam https://www.vivanews.com/berita/politik/10702-sederet-milenial-yang-jadi-anggota-dpr?medium=au tonext dikases 1 Maret 2020.

${ }^{35}$ Hery Syahrullah, "Rusdi Masse Garap Pinrang, Ini Harapan Tokoh Masyarakat" dalam https://makassar.tribunnews.com/2019/02/02/rusdi-masse-garap-pinrang-ini-harapan-tokoh-masyarakat diakses 1 Maret 2020.
} 
Ali menyumbang dana sebesar Rp. 5,9 miliar. Ahmad Ali sebelumnya menjabat sebagai anggota DPR RI Fraksi Nasdem pada periode 2014-2019. Sebelum maju ke Senayan, Ahmad Ali menjabat sebagai anggota DPRD Kabupaten Morowali periode 2009-2014. Ahmad Ali adalah figur yang "dituahkan" di Sulawesi Tengah karena masa-masa mudanya dihabiskan sebagai aktivis. Ahmad Ali adalah pengurus Pemuda Pancasila sejak 1999 dan pengurus Himpunan Mahasiswa Indonesia (HMI) Cabang Palu sejak 1998.

\section{c. Harga Citra}

Citra Nasdem tidak bisa dipisahkan dengan sosok Surya Paloh yang juga sebagai Ketua Umum Nasdem. Meskipun Surya Paloh bukan satu-satunya tokoh di balik faktor keberhasilan Nasdem pada Pemilu 2014 dan 2019, akan tetapi Surya Paloh punya kemampuan untuk memprediksi perolehan suara Nasdem di Pemilu 2019. Bahkan Surya Paloh memprediksi Nasdem berada di posisi tiga besar, walaupun hasilnya Nasdem tidak mencapai posisi itu, tapi pencapaian Nasdem sudah sangat membanggakan mengingat Nasdem adalah partai baru. ${ }^{36}$ Selain itu, bisnis Surya Paloh juga menjadi salah satu faktor kebesaran Nasdem karena relasi orang berbisnis sangat luas dengan rekan sesama bisnis. Surya Paloh tercatat sebagai orang terkaya ke-77 di Indonesia. Surya Paloh memiliki bisnis media dan bisnis katering terkemuka di Asia Tenggara, sehingga dengan kekayaan yang Surya Paloh miliki bisa membangun citra partai politik yang ia pimpin.

\section{Gambar 3}

Berita-berita di Media Massa Online

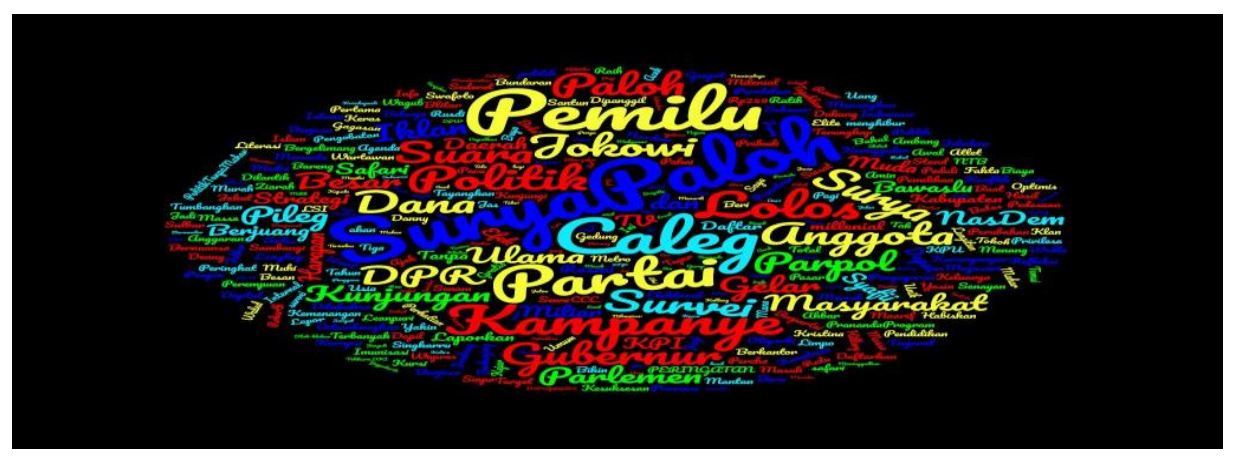

Sumber: Diolah oleh penulis melalui aplikasi wordcloud.com

\footnotetext{
${ }^{36}$ Pinter Politik, "Siasat Oligarki, Misteri Keunggulan Nasdem” dalam https://www.pinterpolitik .com/siasat-oligarki-misteri-keunggulan-nasdem/ diakses 3 Maret 2020.
} 
Gambar 3 menunjukkan, bahwa kata yang paling menonjol setidaknya ada tiga, yaitu "Surya Paloh", "kampanye”, dan "gubernur". Dengan demikian, Gambar 3 tersebut semakin memperkuat, bahwa di antara empat indikator dari teori mix marketing, harga (terutama harga citra) merupakan indikator yang paling berpengaruh terhadap kemenangan Nasdem pada Pemilu 2019. Harga citra lebih dominan dapat terlihat pada citra Surya Paloh sebagai Ketua Umum Nasdem yang sangat berpengaruh terhadap kenaikan perolehan suara partai karena Surya sering melakukan kunjungan ke berbagai daerah selama masa kampanye terutama untuk memberikan bekal politik kepada para caleg. Selain itu, Nasdem memang berusaha merangkul para tokoh daerah seperti gubernur dan anak gubernur yang juga dicalonkan sebagai caleg. Citra Nasdem sebagai partai pendukung pemerintahan Jokowi juga mempengaruhi masyarakat untuk memilih Nasdem. Pada Pemilu 2019, selain PDI-P, Nasdem juga setidaknya merasakan efek ekor jas (cottail effects) Jokowi meskipun Jokowi bukan kader Nasdem.

\section{Penempatan/Distribusi (Place)}

a. Local Network

Demi bersaing di papan atas Pemilu 2019, setiap kader atau caleg Nasdem akan terjun ke masyarakat untuk mengkampanyekan partainya dengan tujuan bisa mengambil hati masyarakat. Banyak kader yang habis-habisan di lapangan untuk berorasi politik, para caleg juga melakukan kegiatan-kegiatan yang sifatnya bisa mengambil hati masyarakat.

Caleg Nasdem mengandalkan kampanye terbuka dengan menyediakan panggung. Selain itu, caleg Nasdem rata-rata melakukan pendekatan yang akrab dengan kaum milenial seperti event Futsal dan Band. Meskipun begitu, ada juga caleg Nasdem yang melakukan pendekatan dengan cara tatap muka atau kampanye dialogis dengan masyarakat. $^{37}$

\section{b. Canvassing}

Dalam mengumpulkan massa, caleg Nasdem punya cara sendiri-sendiri, tergantung latar belakang caleg dan kemampuannya dalam berkomunikasi dengan

${ }^{37}$ Putra Ananda, "Kampanye NasDem Meriah" dalam https://mediaindonesia.com/read /detail /227653-kampanye-nasdem-meriah diakses 1 Maret 2020. 
masyarakat. Prananda Surya Paloh misalnya, dia memiliki strategi untuk merangkul kaum milenial dengan cara membuat berbagai macam kegiatan yang disenangi anak muda seperti turnamen Futsal dan acara musik. Caleg Nasdem melakukan cara-cara yang unik sesuai dengan latar belakang pekerjaan mereka. Ada yang melakukan pengobatan gratis, swafoto dengan patung replika Jokowi, melakukan aksi menari mengelilingi perkampungan dan yang terakhir melakukan pendekatan melalui sepakbola karena profesinya sebagai pelatih sepakbola. ${ }^{38}$

\section{c. Leader Tour}

Nasdem mengandalkan kemampuan komunikasi politik Surya Paloh. Surya Paloh melakukan kunjungan-kunjungan ke organisasi keagamaan seperti Muhammadiyah dan NU. Surya Paloh juga menyempatkan bersilaturahmi dengan pesantren-pesantren di sejumlah daerah. Surya Paloh minim dalam melakukan kunjungan ke elite partai politik kecuali dengan koalisinya sendiri yaitu Koalisi Indonesia Kerja (KIK). Dalam menghadapi Pemilu 2019 baik itu pileg maupun pilpres, Ketua Umum Nasdem, Surya Paloh berkeliling Indonesia dengan maksud konsolidasi dengan tokoh-tokoh masyarakat yang ada di daerah sekaligus mendampingi para caleg untuk berkampanye dan mengkampanyekan Jokowi sebagai calon Presiden. Meskipun Nasdem bukanlah partai Islam, Surya Paloh sering sekali mengunjungi tokoh-tokoh Islam di berbagai daerah yang tersebar di Indonesia. ${ }^{39}$

\section{Promosi (Promotion)}

\section{a. Pull Political Marketing}

Pada masa kampanye, setiap partai politik menggunakan strategi kampanye melalui media massa baik cetak, online, dan elektronik seperti televisi dan radio. Meskipun kampanye melalui media elektronik terbilang efisien akan tetapi ada aturanaturan yang harus ditaati oleh setiap partai politik yang berkompetisi dalam berkampanye. Semuanya telah diatur dalam peraturan KPU No. 23 tahun 2018,

${ }^{38}$ Redaksi WE Online, "Surya Paloh: NasDem Punya Strategi Rahasia Supaya Menang Tiga Besar Dalam Pemilu 2019" dalam https://www.wartaekonomi.co.id/read211246/surya-paloh-nasdempunya-strategi-rahasia-supaya-menang-tiga-besar-dalam-pemilu-2019.html diakses 2 Maret 2020.

39 Putra Ananda, "Ini Alasan Surya Paloh Rutin Lakukan Kunjungan Ke Daerah" dalam https://mediaindonesia.com/read/detail/211838-ini-alasan-surya-paloh-rutin-lakukan-kunjungan-kedaerah dikases 1 Maret 2020. 
misalnya konten dari iklan dan durasi iklannya. Dalam kurun waktu dua bulan masa deklarasi hingga peresmian capres-cawapres Pemilu 2019, setidaknya ada empat partai yang mulai beriklan di televisi. Pada Agustus 2018, PAN menganggarkan Rp. 40 juta untuk belanja iklan televisi. Kemudian PPP tercatat mengeluarkan anggaran belanja iklan hingga Rp. 9.930 juta. Sementara Nasdem telah mengeluarkan ongkos sebesar Rp. 360 juta. Hanya Perindo yang mengeluarkan biaya belanja iklan paling tinggi. Partai milik dari Hary Tanoe itu telah belanja iklan mencapai Rp. $117.925,84$ juta. $^{40}$

Selain itu, iklan partai politik di media elektronik juga tidak semasif Pemilu 2014, berkaca pada Pemilu 2014, Komisi Penyiaran Indonesia (KPI) menghimbau stasiun-stasun TV terutama yang berafiliasi dengan partai politik seperti MNC Group dan Metro TV agar mengedepankan independesi dalam melakukan penyiaran, yang terkadang ada stasiun TV menyelipkan kampanye-kampanye dalam setiap acara. ${ }^{41}$

\section{b. Publikasi Event}

Dalam menarik perhatian massa, Nasdem menyiapkan 120 mobil panggung disebar selama masa kampanye untuk menghibur warga yang menonton. Dangdutan di pasar atau alun-alun dengan caleg yang sekaligus artis dianggap sebagai salah satu sarana jitu untuk memperkenalkan diri dan visi misi partai. ${ }^{42}$ Nasdem memang banyak melakukan publikasi event dangdutan di daerah-daerah, tapi ada juga caleg yang melukan pendekatan yang berbeda seperti mendatangi suatu tempat untuk langsung tatap muka dengan masyarakat. Namun pada Pemilu 2019, Nasdem lebih memperbanyak kegiatan-kegiatan anak muda seperti Futsal dan acara musik untuk menarik perhatian kaum milenial.

\section{Kesimpulan}

Artikel ini menganalisa strategi kampanye Nasdem dengan menggunakan empat indikator dari teori mix marketing yang juga dikenal dengan 4P: product, price, place, dan promotion. Pada indikator product, ada tiga hal yang dibahas. Pertama, slogan

\footnotetext{
${ }^{40}$ Desi Purnamasari, "Partai Mana Juara Belanja Iklan Di TV?" dalam https://tirto.id/partaimana-juara-belanja-iklan-di-tv-c6YV diakses 1 Maret 2020.

${ }^{41}$ Perdana, "Media Massa dan Pemilu, Sebuah Refleksi" dalam https://radarsolo. jawa pos.com/read/2019/02/01/117185/media-massa-dan-pemilu-sebuah-refleksi diakses 1 Maret 2020.

${ }^{42}$ Sri Yanti Nainggolan, "Jebakan Kampanye Digital" dalam https://www.medcom.id /telusur/medcom-files/RkjzQBRk-jebakan-kampanye-digital diakses 3 Maret 2020.
} 
"Politik Tanpa Mahar" dan "Nasdem Partaiku, Jokowi Presidenku" adalah platform yang dipopulerkan oleh Nasdem. Kedua, setia menjadi pendukung Jokowi sejak Pemilu 2014 dan satu-satunya partai baru yang lolos ke parlemen pada Pemilu 2014 adalah sejumlah track record positif partai besutan Surya Paloh ini. Ketiga, mayoritas caleg Nasdem didominasi oleh pengusaha adalah karakteristik personal yang dijual oleh partai ini. Pada indikator price, ada tiga hal yang dibahas. Pada poin harga ekonomi, total dana kampanye Nasdem adalah sekitar Rp. 259 miliar. Angka ini tentu belum ditambah lagi oleh pengeluaran lain yang tidak terhitung. Pada poin harga psikologis, Nasdem kuat di lima Dapil: Papua, Papua Barat, NTT 2, Sulsel 3 dan Sulteng. Pada poin harga citra, Nasdem mengandalkan kekuatan citra Surya Paloh.

Pada indikator place, ada tiga hal yang dibahas. Pada poin local network, Nasdem mengandalkan latar belakang profesi dan kehebatan masing-masing caleg di daerah-daerah. Pada poin canvassing, Nasdem mengandalkan kekreativitasan caleg dalam mengumpulan massa terutama yang menarik perhatian anak muda. Pada poin leader tour, Nasdem memaksimalkan pertemuan dengan tokoh agama baik itu NU maupun Muhammadiyah serta berkunjung ke pesantren-pesantren. Nasdem ingin mencitrakan dirinya sebagai partai religius-nasionalis. Pada indikator promotion, ada dua hal yang dibahas. Pada poin pull political marketing, Nasdem masih mengandalkan stasiun TV (terutama Metro TV dan jaringannya). Selain mengandalkan Metro TV, Nasdem juga melakukan publikasi di media sosial seperti Instagram dan website partai. Pada poin publikasi event, Nasdem mengoptimalkan kegiatan yang menarik perhatian massa terutama anak muda, seperti konser musik untuk menarik perhatian generasi milenial dan senam pagi untuk menarik perhatian ibu-ibu.

\section{Ucapan Terima Kasih}

Penulis mengucapkan terima kasih kepada Lembaga Penelitian, Publikasi dan Pengembangan Masyarakat (LP3M) Universitas Muhammadiyah Yogyakarta atas dukungan dana hibahnya sehingga penelitian ini selesei dan dapat dipublikasian secara luas kepada masyarakat. 


\section{DAFTAR PUSTAKA}

Diana, Yunicha \& Robi Cahyadi Kurniawan. "Konflik Internal Partai NasDem Dan Pemilihan Legislatif 2014" dalam Jurnal Wacana Politik, Vol. 1, No. 1 (2016), h. 22-28.

Firmanzah. Mengelola Partai Politik: Komunikasi dan Positioning Ideologi Politik Di Era Demokrasi. Jakarta: Yayasan Obor, 2008.

Lindawati, Debora Sanur. "Strategi Partai Politik Dalam Menghadapi Pemilu 2014" dalam Jurnal Politica, Vol. 4, No. 2 (2013), h. 287-312.

Mahmud, Insan. "Strategi Pemenangan Partai Keadilan dan Persatuan Indonesia (PKPI) dan Partai Keadilan Sejahtera (PKS) dalam Pemilu Legislatif Kota Salatiga Tahun 2009" dalam Politika: Jurnal Ilmu Politik, Vol. 9, No.1 (2018), h. 47-59.

McNaught, Carmel \& Paul Lam. "Using Wordle as a Supplementary Research Tool" dalam The Qualitative Report, Vol. 15, No. 3 (2010), h. 630-643.

Moleong, Lexi J. Metode Penelitian Kualitatif. Bandung: PT Remaja Rosdakarya, 2012.

Neumann, S. "Toward a Comparative Study of Political Parties" dalam H. Eckstein \& D.E. Apter (Eds.). Comparative Politics: A Reader. New York: The Free Press, 1963.

Nurjaman, Asep. "Party Survival: Strategi Meraih Kursi di Era Reformasi" dalam Jurnal Humanity, Vol. 9, No. 2 (2014), h. 12-24.

Nursal, Adman. Political Marketing: Strategi Memenangkan Pemilu Sebuah Pendekatan Baru Kampanye Pemilihan DPR, DPD, Presiden. Jakarta: PT Gramedia Pustaka, 2004.

Ramadhanil, Fadli, Veri Junaidi \& Ibrohim. Desain Partisipasi Masyarakat Dalam Pemantauan Pemilu, Desain Partisipasi Masyarakat Dalam Pemantauan Pemilu. Jakarta: Kemitraan bagi Pembaruan Tata Pemerintahan di Indonesia bekerjasama Perludem, 2015.

Yusuf, A. Muri. Metode Penelitian: Kuantitatif, Kualitatif \& Penelitian Gabungan. Jakarta: Kencana, 2017.

Yutanti, Widya. "Aktivitas dan Strategi Kehumasan Partai Politik Menjelang Pemilu 2004 (Studi pada Enam Partai Politik Besar di Kota Malang)" dalam HUMANITY, Vol. II, No. 1 (2006), h. 76-85. 


\section{Website}

Adam, Riski. "Partai Nasdem Akui Konflik Internal" dalam https://www.liputan6. com/news/read/487148/partai-nasdem-akui-konflik-internal diakses 2 Maret 2020.

Adnan, Sobih AW. "Membumikan Gagasan Politik Tanpa Mahar" dalam https://www. medcom.id/pilar/fokus/aNrDZl2k-membumikan-gagasan-politik-tanpa-mahar diakses 3 Maret 2020.

Ananda, Putra. "Ini Alasan Surya Paloh Rutin Lakukan Kunjungan Ke Daerah" dalam https://mediaindonesia.com/read/detail/211838-ini-alasan-surya-paloh-rutin-laku kan-kunjungan-ke-daerah dikases 1 Maret 2020.

_-“Kampanye NasDem Meriah” dalam https://mediaindonesia.com/read /detail /227653-kampanye-nasdem-meriah diakses 1 Maret 2020.

Aziza, Kurnia Sari. "Resmi, Nasdem Dukung Pencapresan Jokowi" dalam https:// nasional.kompas.com/read/2014/04/12/1322388/Resmi.Nasdem.Dukung.Pencap resan.Jokowi diakses 4 Maret 2020.

Beritasatu.com. "Roberth Rouw Raih Suara Terbanyak Caleg DPR dari Papua" dalam https://www.beritasatu.com/politik/555060/roberth-rouw-raih-suara-terbanyakcaleg-dpr-dari-papua dikases 2 Maret 2020.

CNN Indonesia. "infografis: daftar anggota dpr 2014-2019 terjerat korupsi” dalam https://www.cnnindonesia.com/nasional/20190919085039-35431798/infografisdaftar-anggota-dpr-2014-2019-terjerat-korupsi diakses 3 Maret 2020.

Detik.com. "NasDem Kejar 3 Besar Di Pemilu 2014" dalam https://news.detik. com/ berita/d-2183789/nasdem-kejar-3-besar-di-pemilu-2014 diakses 1 Maret 2020.

Farisa, Fitria Chusna. "Ini Hasil Lengkap Pemilu Legislatif 2019 yang Ditetapkan KPU” dalam https://nasional.kompas.com/read/2019/05/21/05000061/ini-hasillengkap-pemilu-legislatif-2019-yang-ditetapkan-kpu diakses 3 Maret 2020.

Herlina, Lina. "Resmi Gabung NasDem, Gubernur Sulsel Ikut Safari Politik Surya Paloh" dalam https://mediaindonesia.com/read/detail/150489-resmi-gabungnasdem-gubernu r-sulsel-ikut-safari-politik-surya-paloh diakses 3 Maret 2020.

Ihsanuddin. "Survei Litbang "Kompas", 7 Partai politik Terancam Tak Lolos Ke Senayan" dalam https://nasional.kompas.com/read/2019/03/21/08302401/surveilitbang-kompas-7-partai politik-terancam-tak-lolos-ke-Senayan?page=all diakses 4 Maret 2020. 
jpnn.com. "Peringkat Partai Politik Hasil Survei LSI Denny JA: Perindo di Atas PAN, PPP, Nasdem" dalam https://www.jpnn.com/news/peringkat-parpol-hasil-surveilsi-denny-ja-perindo-di-atas-pan-ppp-nasdem diakses 1 Maret 2020.

Komisi Pemilihan Umum RI. "Hasil Hitung Suara Legislatif DPR RI 2019" dalam https://pemilu2019.kpu.go.id/\#/dprri/hitung-suara/ diakse 1 Maret 2020.

Nainggolan, Sri Yanti. "Jebakan Kampanye Digital” dalam https:/www.medcom.id/tel usur/medcom-files/RkjzQBRk-jebakan-kampanye-digital diakses 3 Maret 2020.

Nulangi, Tommy Mbenu. "Kristina Muki Target Perolehan 100.000 Lebih Suara" dalam https://kupang.tribunnews.com/2019/04/12/kristina-muki-target-perolehan-1000 00-lebih-suara diakses 1 Maret 2020.

Nuralam, Candra Yuri. "Cerita NasDem dan Politik Tanpa Mahar" dalam https://www .medcom.id/nasional/politik/lKYBLrjN-cerita-nasdem-dan-politik-tanpa-mahar diakses 1 Maret 2020.

Papuasatu.com. "Kemenangan Partai NasDem Akan Dimulai Dari Kabupaten Tolikara" dalam https://papuasatu.com/polhukrim/kemenangan-partai-nasdem-akan-dimu lai-dari-kabupaten-tolikara/ diakses 1 Maret 2020.

Perdana. "Media Massa dan Pemilu, Sebuah Refleksi" dalam https://radarsolo. jawa pos.com/read/2019/02/01/117185/media-massa-dan-pemilu-sebuah-refleksi diakses 1 Maret 2020.

Pinter Politik. "Siasat Oligarki, Misteri Keunggulan Nasdem" dalam https://www. pinterpolitik .com/siasat-oligarki-misteri-keunggulan-nasdem/ diakses 3 Maret 2020.

Prabowo, Dani. "Disahkan KPU, Ini Perolehan Suara Pemilu Legislatif 2014" dalam https://nasional.kompas.com/read/2014/05/09/2357075/Disahkan.KPU.Ini .Perolehan.Suara.Pemilu.Legislatif.2014 diakses 3 Maret 2020.

Prasetya, Andhika. "Dapat 2,1\% di Survei, NasDem: Keliru Jika Tak Lolos DPR" dalam https://news.detik.com/berita/d-4124197/dapat-21-di-survei-nasdem-keli ru-jika-tak-lolos-dpr diakses 1 Maret 2020.

Purnamasari, Desi. "Partai Mana Juara Belanja Iklan Di TV?" dalam https://tirto.id /partai-mana-juara-belanja-iklan-di-tv-c6YV diakses 1 Maret 2020.

Putra, Nanda Perdana. "Hasil Survei Pileg 2019, Siapa Lolos Masuk Parlemen?” dalam https://www.liputan6.com/news/read/3934050/hasil-survei-pileg-2019-siapalolos-masuk-parlemen diakses 1 Maret 2020. 
Putri, Budiarti Utami. "Deretan Caleg Partai NasDem, dari Bekas Menteri Hingga Artis" dalam https://nasional.tempo.co/read/1107986/deretan-caleg-partai-nasd em-dari-bek as-menteri-hingga-artis diakses 1 Maret 2020.

Redaksi WE Online. "Politik Tanpa Mahar NasDem Positif? Ini Kata Pengamat" dalam https://www.wartaekonomi.co.id/read214409/politik-tanpa-maharnasdem-positif-ini-kata-pengamat.html diakses 2 Maret 2020.

-------.."Surya Paloh: NasDem Punya Strategi Rahasia Supaya Menang Tiga Besar Dalam Pemilu 2019" dalam https://www.wartaekonomi.co.id/read21 1246/surya-paloh-nasdem-punya-strategi-rahasia-supaya-menang-tiga-besardalam-pemilu-2019.html diakses 2 maret 2020.

Ruqoyah, Siti \& Lilis Khalisotussurur. "Sederet Milenial yang Jadi Anggota DPR" dalam https://www.vivanews.com/berita/politik/10702-sederet-milenial-yangjadi-anggota-dpr?medium=au tonext dikases 1 Maret 2020.

Suwarta, Thomas Harming. "NasDem Laporkan Dana Kampanye Rp259 Miliar Ke KPU” dalam https://mediaindonesia.com/read/detail/238895-nasdem-laporkandana-kampan ye-rp259-miliar-ke-kpu diakses 1 Maret 2020.

Syahrullah, Hery. "Rusdi Masse Garap Pinrang, Ini Harapan Tokoh Masyarakat" dalam https://makassar.tribunnews.com/2019/02/02/rusdi-masse-garap-pinrang-ini-hara pan-tokoh-masyarakat diakses 1 Maret 2020. 